\title{
KAJI TINDAK PENGGUNAAN MEDIA SOSIAL SEBAGAI SARANA PEMASARAN PRODUK KERAJINAN PADA ERA NEW NORMAL (STUDI KASUS PADA USAHA KERAJINAN BATOK BUAH BERENUK)
}

\author{
ACTION RESEARCH OF SOCIAL MEDIA APPLICATION AS A \\ MARKETING TOOLS OF HANDICRAFT PRODUCT IN THE NEW \\ NORMAL ERA \\ (CASE STUDY ON CALABASH SHELL CRAFT BUSINESS)
}

\author{
Netti Nurlenawati ${ }^{1)}$, Sari Marliani ${ }^{2)}$, July Yuliawati ${ }^{3)}$ \\ ${ }^{1)}$ Program Studi Manajemen, ${ }^{2)}$ Program Studi Akuntansi, ${ }^{3)}$ Program Studi Manajemen \\ Fakultas Ekonomi dan Bisnis Universitas Buana Perjuangan Karawang \\ ${ }^{1)}$ netti.nurlenawati@ubpkarawang.ac.id ${ }^{2)}$ sari.marliani@ubpkarawang.ac.id \\ ${ }^{3)}$ July.yuliawati5@gmail.com
}

\begin{abstract}
ABSTRAK
Penelitian ini bertujuan untuk memberikan solusi atas masalah yang dihadapi mitra dalam mempromosikan produk kerajinan batok buah berenuk dengan penggunaan media sosial.

Penelitian menggunakan pendekatan kualitatif dan metode penelitian tindakan yang dilaksanakan pada bulan April sampai dengan Oktober 2021 di tempat produksi kerajinan batok buah berenuk, Dusun Sumedangan Desa Purwadana Kecamatan Telukjambe Timur Kabupaten Karawang. Penelitian dilakukan melalui tahapan diagnosis permasalahan, perencanaan tindakan, pelaksanaan tindakan, evaluasi dan tahap refleksi. Data dikumpulkan dengan cara observasi, wawancara serta analisis dokumen. Analisis data melalui tahap reduksi data, display data dan penarikan kesimpulan/verifikasi.

Hasil dari penelitian adalah masyarakat memiliki keinginan, kebutuhan dan selera yang berbeda beda, namun sebagian besar masyarakat cenderumg memiliki minat pada produk kerajinan yang memiliki nilai guna tinggi, desain modern, unik, awet dan memiliki kekhasan daerah Indonesia. Produk kerajinan batok buah berenuk memiliki peluang untuk dikembangkan menjadi usaha kerajinan khas daerah Karawang. Produk kerajinan batok buah berenuk belum memiliki pesaing dalam pasar online, sehingga memiliki peluang untuk dipromosikan dan dipasarkan melalui media sosial.
\end{abstract}

Kata Kunci: kaji tindak, pemasaran, kerajinan batok buah berenuk.

\section{ABSTRACT}

This study aims to provide solutions to problems faced by partners in promoting calabash shell craft products using social media. 
The study used a qualitative approach and action research methods which were carried out from April to October 2021 at the calabash craft production site, Sumedangan Hamlet, Purwadana Village, Telukjambe Timur District, Karawang Regency. The research was conducted through the stages of problem diagnosis, action planning, action implementation, evaluation and reflection stages. Data were collected by observation, interviews and document analysis. Data analysis uses the Miles and Huberman model which was data reduction, data display and drawing conclusions/verification.

The result of the research is that people have different desires, needs and tastes, but most people tend to have an interest in handicraft products that have high use value, modern designs, unique, durable and have the peculiarities of the Indonesian region. Calabash shell craft products have the opportunity to be developed into a craft business typical of the Karawang area. Calabash shell craft products do not yet have competitors in the online market, so they have the opportunity to be promoted and marketed through social media.

Keywords: action research, marketing, fruit shell, calabash

\section{PENDAHULUAN}

Era globalisasi dewasa ini menyebabkan semakin tingginya persaingan ekonomi antar negara. Persaingan ini menyebabkan setiap negara berupaya menggali seluruh potensi sumberdaya yang dimilikinya. Berdasarkan hal ini pemerintah Indonesia memunculkan suatu kebijakan yang menjadi bidang unggulan yaitu ekonomi kreatif.

Kebijakan ini terdapat pada Peraturan Presiden Nomor 72 Tahun 2015 tentang Perubahan Atas Peraturan Presiden Nomor 6 Tahun 2015 Tentang Badan Ekonomi Kreatif yang terdiri dari 16 sub-sektor, salah satunya adalah kriya atau kerajinan tangan. Kebijakan tersebut diharapkan dapat menjadi unggulan bagi Indonesia, mengingat potensi sumberdaya yang dimiliki sangat besar mulai dari sumberdaya alam yang melimpah sampai dengan sumberdaya manusia yang dikenal kreatif.

Pada kenyataannya saat diimplementasikan terdapat berbagai hambatan. Hambatan yang utama adalah adanya pademi COVID-19. Merebaknya kasus COVID-19 atau lebih dikenal dengan virus Corona menyebabkan lumpuhnya kegiatan ekonomi baik nasional maupun internasional (Nurlenawati dkk, 2020).

Di Indonesia kebijakan pembatasan untuk bepergian dan mengunjungi tempat-tempat wisata berdampak sangat besar pada kelancaran implementasi kebijakan ekonimi kreatif, karena sebagian besar subsektor ekonomi kreatif sangat erat kaitannya dengan tempat-tempat wisata. Sejumlah bisnis yang berkaitan dengan berkumpulnya banyak orang nyaris berhenti 
beroperasi. Bisnis tersebut adalah tempat wisata, transportasi, hotel, tempat hiburan dan sebagainya.

Kriya atau kerajinan tangan merupakan salah satu produk yang menurun penjualannya saat pandemi COVID-19 mengingat bisnis ini erat kaitannya dengan pariwisata. Biasanya saat wisata ke suatu daerah orang membeli oleh-oleh yang khas dari daerah tersebut antara lain kerajinan tangan. Menurut Rieke dan Anggela (2019) usaha ini dapat meningkatkan pendapatan masyarakat di sekitar tempat wisata.

Kerajinan dari batok buah berenuk merupakan salah satu kerajinan khas kota Karawang. Kerajinan ini khas produk dari suatu dusun yaitu Dusun Sumedangan Desa Purwadana Kecamatan Telukjambe Timur Kabupaten Karawang dan hanya diusahakan oleh seorang yang bernama Bapak Empud. Usaha ini termasuk salah satu usaha yang terdampak oleh pandemic COVID-19.

Kendala yang ditemui oleh Bapak Empud adalah pengrajin baru memulai usaha, sehingga belum mengenal bagaimana mempromosikan produk sehingga pemasaran kerajinan tersebut sangat terbatas kepada orang-orang yang mengenalnya serta mengetahui produk kerajinan tersebut. Permasalahan bertambah ketika awal tahun 2020 pandemi COVID-19 mulai merebak dan adanya berbagai larangan dari pemerintah yang menyebabkan usaha kerajinan tersebut tidak berjalan lancar. Kendala ini bertambah saat untuk promosipun perlu keahlian digital yang tidak dimiliki oleh Bapak Empud.

Digital Marketing adalah pemasaran yang pelaksanaannya menggunakan media elektronik (dengan kata lain digital marketing adalah penerapan teknologi digital yang membentuk saluran online (channel online) ke pasar (website, e-mail, database, digital TV dan melalui berbagai inovasi terbaru lainnya termasuk di dalamnya blog, feed, podcast, dan jejaring sosial) (Kotler dan Amstrong, 2018).

Selanjutnya Ryan (2014) menyatakan bahwa yang diperlukan oleh pelanggan terhadap digital marketing adalah media dari digital marketing yang memberikan kenyamanan untuk digunakan pelanggan, fitur-fitur dari media digital marketing yang bersifat user centric, pelayanan yang cepat, serta menampilkan kualitas produk yang baik.

Berkaitan dengan kualitas produk kerajinan, suatu produk kerajinan tangan harus memenuhi 5 (lima) syarat meliputi kegunaan, kenyamanan, keluwesan, keamanan dan keindahan (https://oriflameid.com/syarat-syarat-perancangan-benda-kerajinan/). 
Tujuan dari penelitian ini adalah memberikan solusi atas masalah yang dihadapi mitra dalam mempromosikan produk kerajinan batok buah berenuk dengan penggunaan media sosial.

\section{METODE PENELITIAN}

\section{Jenis Penelitian}

Penelitian ini menggunakan desain penelitian kualitatif dengan pendekatan tindakan. Jenis penelitian ini menggunakan action research, dengan tipe tindakan praktis yaitu penelitian berskala kecil terhadap masalah yang terjadi pada suatu tempat.

Tindakan praktis yang dilakukan adalah pengunaan media sosial sebagai sarana pemasaran pada produk kerajinan batok buah berenuk. Penggunaan media sosial tersebut sebagai sarana pemasaran yang diharapkan untuk meningkatkan penjualan pada produk kerajinan batok buah berenuk di Dusun Sumedangan Desa Purwadana Kecamatan Telukjambe Timur Kabupaten Karawang.

\section{Waktu dan Tempat Penelitian}

Penelitian dilakukan pada bulan Mei sampai dengan Oktober 2021 di tempat produksi kerajinan batok buah berenuk, Dusun Sumedangan Desa Purwadana Kecamatan Telukjambe Timur Kabupaten Karawang.

\section{Subjek dan Kolaborator Penelitian}

Subjek pada penelitian ini adalah seorang pengrajin batok buah berenuk bernama Bapa Empud, seorang mantan Ketua RT di Dusun Sumedangan yang pertama kali menekuni kerajinan batok buah berenuk di Dusun Sumedangan, ditemukan oleh mahasiswa KKN UBP Karawang pada tahun 2018.

Subjek adalah seorang tokoh masyarakat di Dusun Sumedangan, kreatif dan inovatif untuk memanfaatkan sumberdaya lokal menjadi suatu produk yang bernilai ekonomi, salah satunya adalah kerajinan buah berenuk.

Kualitas produk meliputi model, varian, keunikan sudah bagus tapi permasalahan pada pemasaran terutama saat pandemi.

Kolaborator terdiri dari dosen dan mahasiswa. Dosen terdiri dari: 
1. Dosen bidang manajemen pemasaran yang bertugas untuk menentukan tindakan strategi pemasaran yang harus dilakukan untuk solusi peningkatan penjualan pada kerajinan batok buah berenuk serta menganalisis hasil, serta evaluasi dan perbaikan.

2. Dosen bidang manajemen sumberdaya manusia yang bertugas untuk memberikan pelatihan dan pendampingan kepada subjek.

3. Mahasiswa Program Studi Manajemen yang bertugas memotret, memberikan konten, membuat sosial media dan secara teknis membantu mengajari subjek.

\section{Prosedur Penelitian}

Kegiatan yang dilakukan pada penelitian ini meliputi beberapa tahap yaitu tahap dianogsis permasalahan, perencanaan tindakan, pelaksanaan tindakan, evaluasi dan refleksi.

Tahap diagnosis permasalahan adalah tahap menganalisis masalah pokok dengan cara observasi dan wawancara dengan mitra.

Tahap perencanaan tindakan adalah tahap menyusun rencana dan persiapan tindakan untuk mengenalkan produk kerajinan batok buah berenuk dengan cara penggunaan media sosial untuk mitra.

Tahap pelaksanaan tindakan adalah tahap melaksanakan tindakan pengenalan dan penggunaan media sosial pada mitra.

Tahap evaluasi adalah tahap melakukan evaluasi penggunaan media sosial pada produk kerajinan batok buah berenuk.

Tahap refleksi adalah upaya untuk mengkaji apa yang telah dihasilkan dan apa yang belum berhasil dituntaskan dengan tindakan yang telah dilakukan, Hasil refleksi digunakan untuk menetapkan langkah selanjutnya untuk mencapai tujuan penelitian tindakan.

\section{Data, Instrumen, dan Teknik Pengumpulan Data}

Berdasarkan sumbernya data yang diperoleh di lapangan terbagi menjadi dua yaitu data primer dan data sekunder.

Data primer yang berupa data hasil observasi dan wawancara dengan mitra selama penelitian berlangsung. 
Data sekunder yang berupa dokumen foto dan data dari hasil penelitian terdahulu yang diperoleh dengan teknik studi pustaka.

\section{Teknik Analisis Data}

Analisis data dilakukan pada saat pengumpulan data berlangsung dan setelah selesai pengumpulan data. Analisis data di lapangan menggunakan model Miles dan Huberman dalam Sugiyono (2015). Aktivitas analisis data dilakukan secara interaktif dan berlangsung secara terus-menerus sampai tuntas, sehingga datanya sudah jenuh. Analisis data meliputi reduksi data (data reduction), Display data (data display) dan penarikan kesimpulan/verifikasi (conclusion drawing/verification).

\section{HASIL PENELITIAN DAN PEMBAHASAN}

\section{Tahap Diagnosis}

\section{Profil Mitra}

Bapak Empud merupakan seorang tokoh masyarakat di Dusun Sumedangan Desa Purwadana Kecamatan Telukjambe Timur Kabupaten Karawang. Pekerjaan tetap bapak Empud seharihari adalah tukang (pekerja) bangunan khususnya untuk pembangunan rumah. Pada tahun 2018 bersama-sama mahasiswa KKN (Kuliah Kerja Nyata) UBP angkatan 2015 mencoba membuat kerajinan buah berenuk. Produk awal berupa celengan yang kemudian dikembangkan menjadi berbagai macam produk kerajinan. Ciri khas yang dimiliki kerajinan bapak Empud ini dibandingkan dengan kerajinan buah berenuk yang lain yaitu dari warna yang khas menggunakan warna coklat pernis serta tali yang menggunakan serat pohon pisang. Semua bahan kerajinan dia peroleh dari sumberdaya alam yang ada di Dusun Sumedangan.

Setelah menemukan kerajinan ini yang sesuai dengan hobbynya maka dia menekuni pekerjaan pengrajin ini sebagai pekerjaan sampingan, sedangkan pekerjaan utama yaitu sebagai tukang (pekerja) bangunan tetap dijalani.

Sebagai pendatang baru dalam bisnis kerajinan batok buah berenuk, produk Bapak Empud belum dikenal oleh masyarakat umum maupun penggemar kerajinan. Promosi produk kerajinan tersebut saat itu dibantu oleh mahasiswa KKN UBP Tahun 2018-2018, antara lain melalui:

1. Pameran Lokakarya KKN UBP Karawang Tahun 2018-2018 Tingkat Kecamatan pada tanggal 28 Juli 2018 di Kantor Kecamatan Telukjambe Timur, serta Tingkat Kabupaten pada 
tanggal 04 Agustus 2018 di Aula Husni Hamid Pemda Kabupaten Karawang sebagai upaya memperkenalkan produk kerajinan buah berenuk khas Karawang.

2. Pameran di kampus UBP Karawang pada Acara Pengenalan Kehidupan Kampus Mahasiswa Baru (PKKMB) Tahun 2018-2019 tanggal 03 September 2018 yang menghadirkan Menristekdikti serta tamu dari Universitas KIBI Jepang.

3. Galeri Produk Kerajinan Batok Buah Berenuk di rumah bapak Empud.

Melalui persahabatan dengan mahasiswa KKN UBP Karawang saat itu bapak Empud mampu memasarkan produk kerajinannya sampai keluar kota antara lain Sukabumi dan Subang. Pembuatan produk berdasarkan pesanan konsumen yang mengetahui via pameran, galeri serta via mahasiswa KKN tersebut.

Harga produk kerajinan pak Empud berkisar antara Rp. 15.000 sampai dengan Rp. 100.000. Harga tersebut ditentukan sesuai dengan kerumitan, penggunaan waktu dan banyaknya modal yang diperlukan saat pembuatan. Harga termurah dipatok pada kerajinan asbak sedangkan harga tertinggi adalah hiasan (pajangan) becak atau kereta/bendi.

Pada periode tahun 2018-2019 (sebelum pandemi), dengan modal sebesar Rp. 3.750.000,00 dan patokan harga seperti itu produksi kerajinan berjalan lancar. Jumlah produk yang terjual rata-rata setiap bulannya antara 8 buah sampai dengan 15 buah, sehingga pada periode tahun tersebut berhasil mengantongi uang sebesar Rp12.000.000,00.

Setelah masa itu berlalu, mahasiswa KKN UBP juga sudah lulus bahkan berakhir dengan adanya pandemic COVID-19 usaha kerajinan milik Bapak Empud kembali memudar bahkan tidak ada lagi pemesanan, namun koleksi produk dan galeri masih dimiliki Bapak Empud. Saat banjir yang melanda Dusun Sumedangan pada bulan Januari - Februari tahun 2021 meluluhlantakan seluruh properti usaha kerajinan Bapak Empud.

\section{Tahap Perencanaan}

Pada tahap ini tim peneliti mengadakan diskusi dengan mitra tentang langkah-langkah yang akan dilakukan. Perencanaan ini meliputi persiapan yang dilakukan sebelum memperkenalkan produk kerajinan melalui media sosial.

\section{Riset pasar mengenai pesaing dan pasar pesaing dalam pasar digital}

Pesaing pada kerajinan berbahan batok buah berenuk di Indonesia belum terlalu banyak. Para pesaing tersebut adalah pengrajin berenuk Cibarusah (http://cibarusahcenter.blogspot.com/2015/05/menariknya-kerajinan-berenuk- 
cibarusah.html), pengrajin berenuk Bogor (https://peluangusaha.kontan.co.id/news/menyulapbuah-maja-menjadi-barang-kerajinan-unik-1), pengrajin berenuk Purwakarta (http://boreleng.blogspot.com/2016/02/membuat-kerajinan-dari-bahan-buah.html?m=1) dan pengrajin berenuk Cikaum Subang.

Masing-masing pengrajin batok buah berenuk memiliki ciri khas dalam desain, warna maupun motif. Harga pada keempat pesaing bersaing. Para pesaing rata-rata memasarkan produknya secara offline di daerah sekitar tempat produksi. Walaupun ada yang menjual melalui telepon, namun belum ada yang membuat toko online di akun instagram, akun facbook, ataupun marketplace.

Dibandingkan dengan pengrajin batok buah berenuk Dusun Sumedangan, keempat pesaing memiliki pengalaman yang lebih lama dalam menggeluti kerajinan batik buah berenuk, mempunyai desain/model yang rapih dan menarik, jangkauan pasar yang lumayan luas serta mempunyai pemasaran offline di sekitar daerah usaha. Walau demikian masih terdapat kelemahan pesaing yaitu belum terekspos luas di pasar online, belum mempunyai toko online, serta desain produk yang monoton.

Apabila dibandingkan dengan produk kerajinan keempat pesaing, kerajinan batok buah berenuk Dusun Sumedangan memiliki keunikan yaitu dapat memproduksi tas selempang dengan model ethnic namun masih kekinian dan cocok digunakan oleh anak muda, selain itu desain lainnya pun tak kalah unik yaitu tas panjang, becak, kaligrafi, boneka salju, petromak dan lain-lain yang belum di produksi oleh pengrajin lainnya.




Produk Kerajinan Batok Buah Berenuk Khas Dusun Sumedangan Karawang Sumber: Dokumentasi penelitian, 2021.

Jika dilihat dari dalam kota Karawang belum ada pesaing yang terlihat memproduksi buah maja untuk dijadikan kerajinan atau hiasan rumah. Namun diluar kota Karawang dan sekitarnya sudah ada yang memproduksi hingga memasarkan kerajinan buah berenuk ini, seperti Cibarusah Bekasi, Bogor, Purwakarta, Subang. Walaupun begitu pesaing yang telah dijelaskan diatas belum membuka toko online di media social manapun ataupun marketplace.

\section{Pengembangan Desain Produk}

Pengembangan desain produk pada penelitian ini meliputi pengembangan desain produk dari fungsi dan keunikan produk serta tampilan produk.

Berdasarkan fungsi dan keunikan produk, desain baru yang dibuat selama penelitian yaitu lampu gantung dan hiasan unik terumbu karang. Lampu ini sangat cocok untuk digunakan sebagai lampu taman atau lampu gantung di café-café. Sedangkan hiasan unik terumbu karang sangat cocok dipasang di meja ataupun buffet.



Lampu gantung dan terumbu karang dari batok buah berenuk

Sumber: Dokumentasi penelitian, 2021

Berdasarkan tampilan produk, desain baru adalah perubahan pada warna produk tampilan dan penggunaan tali pada tas selendang. Pada penelitian ini dilakukan seleksi warna, sehingga 
kerajinan ini memiliki warna khas. Warna yang dipilih adalah warna-warna pelitur yaitu coklat terang, coklat tua serta merah marun.

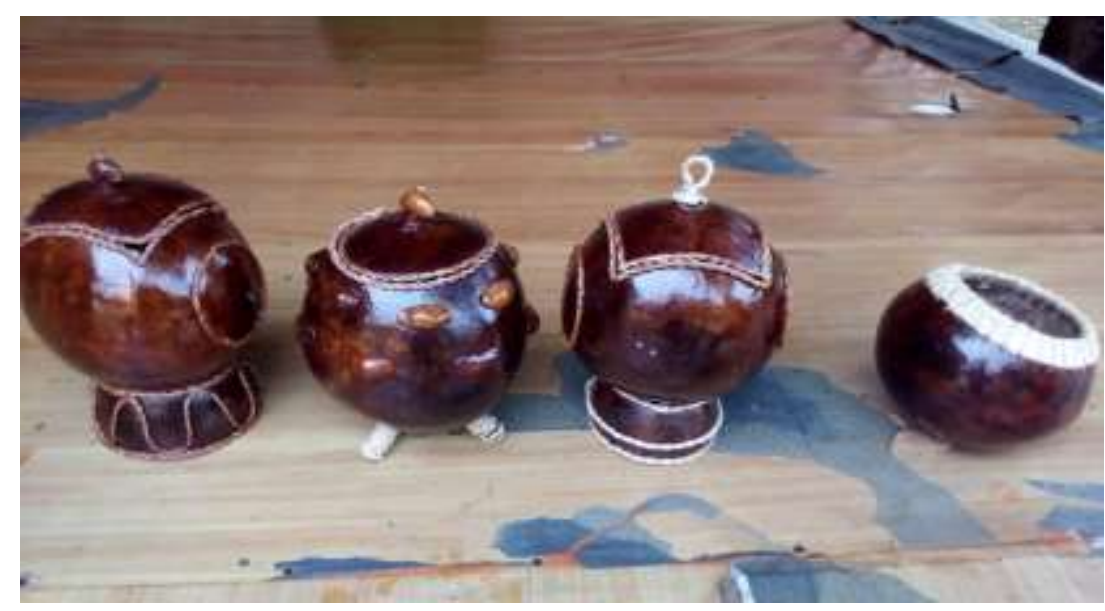

Warna-warna yang dipertahankan saat ini

Sumber: Dokumentasi penelitian, 2021

Tali tas selendang yang semula terbuat dari bahan sejenis nilon kemudian disepakati agar tali tersebut diganti. Saat ini tali tas selendang yang digunakan terbuat dari serat gedebog (batang) pisang. Tali ini menjadi salah satu ciri khas kerajinan tersebut.

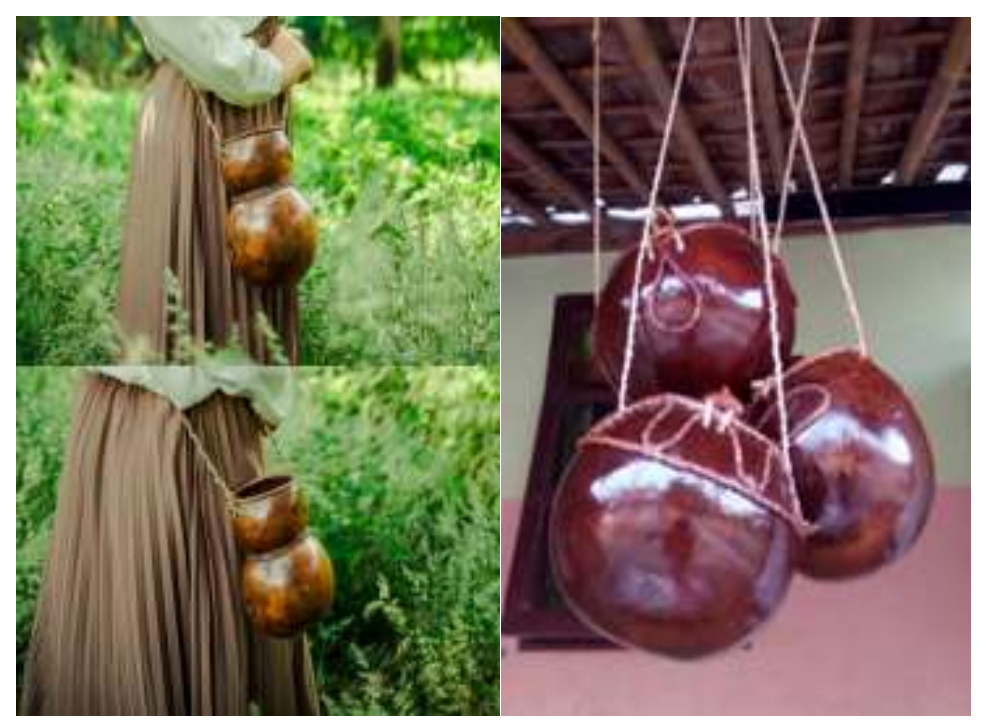

Tali tas terbuat dari bahan nilon (kiri) dan tali tas terbuat dari serat gedebog pisang (kanan) Sumber: Dokumentasi penelitian, 2021

\section{Branding}


Pembuatan merek untuk produk kerajinan batok buah berenuk dimaksudkan agar masyarakat dapat membedakan produk kerajinan berenuk yang diproduksi oleh usaha sejenis. Sebelum promosi melalui media sosial hal ini perlu dilakukan agar saat promosi merek tersebut dapat melekat di benak masyarakat.

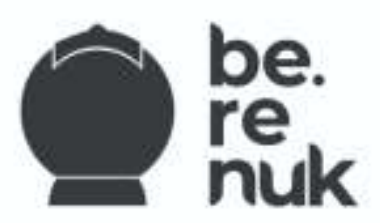

Merek Kerajinan Batok Buah Berenuk Dusun Sumedangan

Sumber: Dokumentasi penelitian, 2021.

\section{$\underline{\text { Pelaksanaan Tindakan }}$}

Tindakan yang dilakukan adalah pelatihan dan pendampingan mengenai pembuatan konsep (konten) promosi, pemotretan produk, serta pembuatan video.

Pelatihan dan pendampingan tersebut membuat para peserta pelatihan memahami dan memiliki keterampilan dalam pembuatan konsep promosi, pemotretan produk serta pembuatan video.

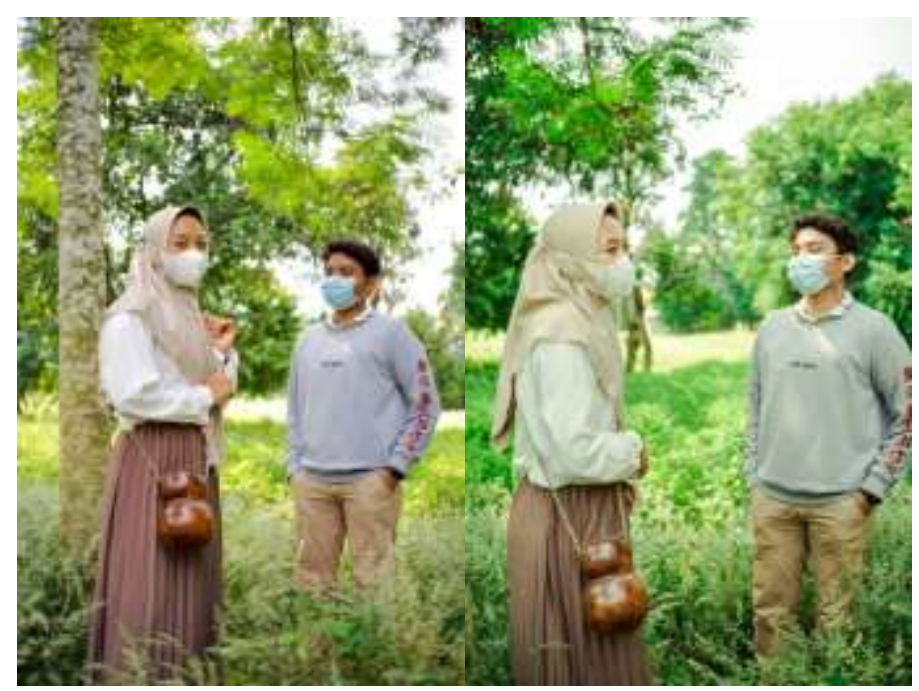



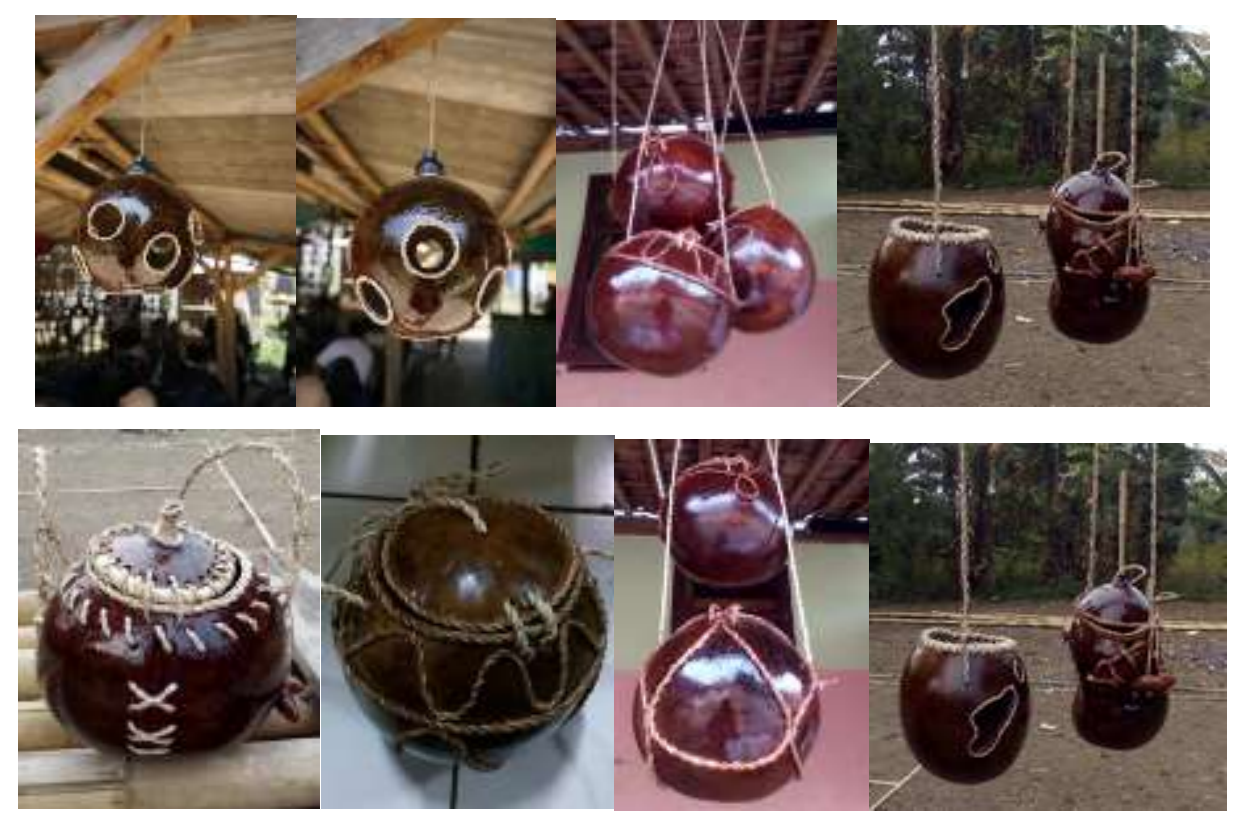

Hasil pemotretan setelah pelatihan

Sumber: Dokumentasi penelitian, 2021

Foto-foto hasil pelatihan diunggah ke instagram dengan akun be.renuk, sedangkan hasil pembuatan video diunggah ke youtube dengan link https://youtu.be/wR1r6jI-10k.

\section{Tahap Evaluasi}

\section{Evaluasi hasil riset pasar pesaing}

Dari hasil riset pasar pesaing maka diperoleh hasil bahwa pasar online masih terbuka lebar untuk pemasaran kerajinan batok buah berenuk Dusun Sumedangan

\section{Evaluasi hasil riset pasar pada pengembangan produk}

Evaluasi dilakukan dengan cara melakukan vote di media sosial instagram untuk mengetahui apakah masyarakat memiliki minat pada produk kerajinan batok buah berenuk dari Dusun Sumedangan tersebut. 


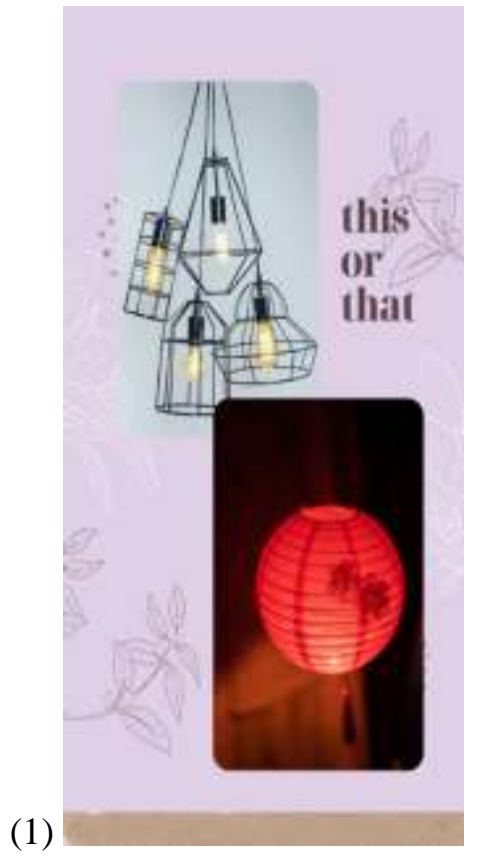

(2)

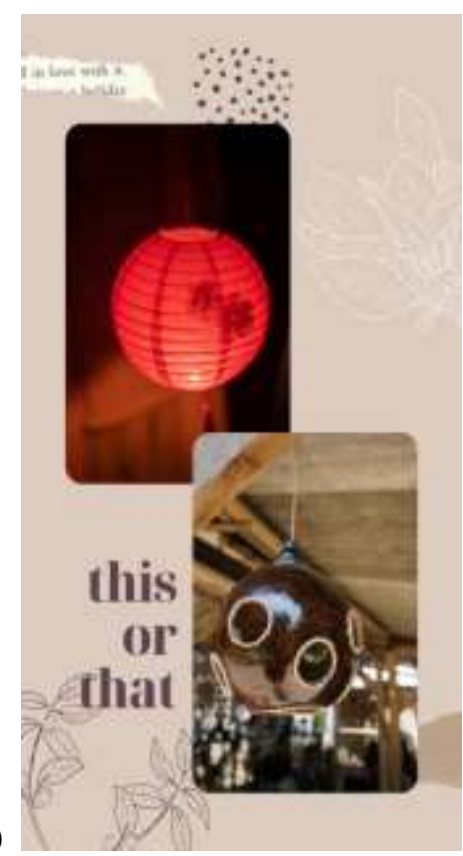

$129 ; 17=146$

\section{Hasil Riset Perbandingan Pengembangan Produk Kerajinan Lampu Gantung}

Sumber: Dokumentasi penelitian, 2021 https://unsplash.com/photos/VtppxC-GfZs https://unsplash.com/photos/pQbE5xPMVOw

Hasil dari evaluasi menunjukkan bahw sebanyak $88 \% 56$ mas 140 arakat 196 memilih desain modern produk pabrik (https://unsplash.com/photos/VtppxC-GfZs), sedangkan 12\% memilih produk hand made atau produk tradisional (https://unsplash.com/photos/pQbE5xPMVOw). Hal ini menunjukkan bahwa sebagian besar masyarakat lebih memiliki minat pada desain modern yang sederhana dan lebih bergaya mutakhir serta cocok untuk digunakan di ruangan manapun dibandingkan dengan desain tradisional seperti lampion yang hanya cocok digunakan di tempat-tempat dan waktu tertentu saja.

Selain itu masyarakat juga diminta untuk memilih satu di antara dua pilihan produk lampu tradisional yaitu lampion (https://unsplash.com/photos/pQbE5xPMVOw) dan produk lampu gantung batok buah berenuk dari Dusun Sumedangan. Hasil menunjukkan bahwa sebanyak $71 \%$ masyarakat memilih desain produk yang dibuat dari bahan baku berenuk dibandingkan dengan produk bahan baku lainnya, karena dipandang kuat, tahan lama dan berbahan dasar yang lebih alami. Selain itu produk ini lebih memiliki kekhasan daerah Indonesia dibandingkan dengan lampion yang bergaya khas negeri China. Dari hasil vote gambar kedua tersebut dapat dipertimbangkan untuk menjadi peluang bagi usaha kerajinan buah berenuk. 
Selain membandingkan dengan produk lain, masyarakat juga diminta untuk memilih produk kerajinan batok buah berenuk dari Dusun Sumedangan yang banyak diminati.

(1)

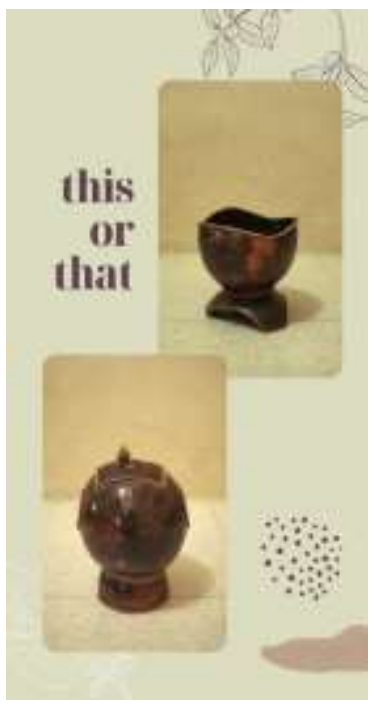

$106 ; 90=196$

$54 \%: 46 \%$

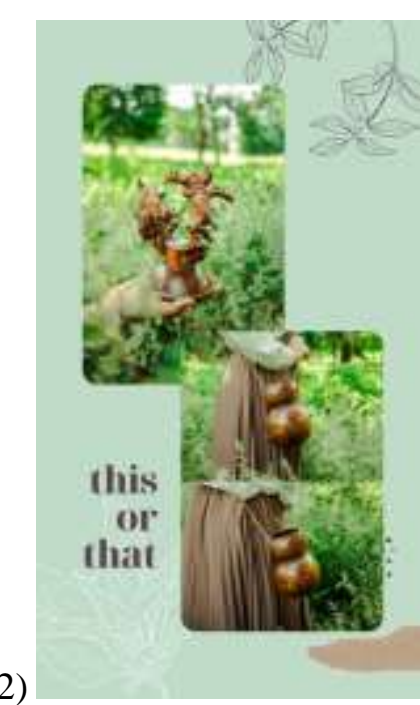

(2)

$$
\begin{gathered}
74 ; 94=168 \\
44 \%: 56 \%
\end{gathered}
$$

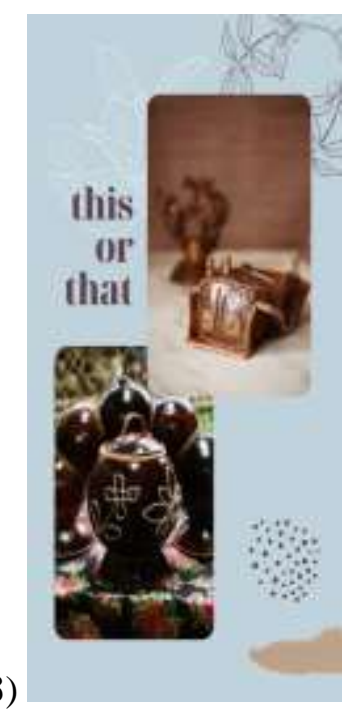

$130 ; 56=176$

$70 \%: 30 \%$

Perbandingan Produk

Sumber: Dokumentasi penelitian, 2021

Dengan menggunakan metode yang sama yaitu vote melalui instagram diperoleh hasil bahwa masyarakat lebih banyak yang memilih toples (54\%) daripada asbak (46\%). Hal ini disebabkan toples lebih multifungsi dibandingkan asbak, selain saat ini semakin sedikit mayarakat yang merokok, toples juga lebih memiliki desain yang menarik, dbandingkan asbak yang sangat sederhana.

Demikian juga pada tas dan terumbu karang, masyarakat lebih banyak berminat pada tas $(56 \%)$ dibandingkan terumbu karang (44\%) walaupun tidak terlalu berbeda. Hal ini menunjukkan bahwa masyarakat lebih berminat pada produk yang jelas memiliki fungsi tertentu, selain unik dan bernuansa ethnic.

Pada gambar ketiga tampak sebagian besar masyarakat memilih toples (70\%), sedangkan pajangan mobil hanya mencapai $30 \%$.

Model terumbu karang mempunyai peminat sebesar 44\% model ini dianggap langka dan unik untuk pajangan dan untuk model pajangan mobil memiliki peminat 30\% karena model ini banyak digunakan oleh pengrajin pajangan mobil yang terbuat dari kayu atau batok kelapa. 


\section{Evaluasi penggunaan instagram dan youtube sebagai media promosi dan pemasaran}

Sampai penelitian ini berakhir pak Empud sebagai pengrajin belum memahami maupun terampil dalam menggunakan media sosial sebagai sarana promosi maupun pemasaran dengan demikian dapat disimpulkan bahwa pengrajin belum dapat mengadopsi teknologi media sosial. Komunitas SUKUN sebagai pembantu atau pendukung pengrajin dalam penggunaan media sosial sangat membantu pada saat penyelenggaraan pelatihan yaitu sebagai peserta pelatihan yang memiliki kesiapan dalam membantu membimbing pengrajin (pak Empud) sehari-hari dalam penggunaan media sosial. Mereka relatif cepat dalam memahami dan menerapkan media sosial baik instagram maupun youtube.

Dari hasil evaluasi tersebut, maka diputuskan untuk pengelola media sosial adalah komunitas SUKUN. Dengan demikian yang menentukan konten dan mengunggah bahan promosi ke media sosial adalah komunitas SUKUN dengan seijin pak Empud sebagai mitra peneliti.

Dari evaluasi pada penggunaan media sosial sebagai sarana promosi maupun pemasaran maka diperoleh hasil bahwa penggunaan media sosial sebagai sarana promosi maupun pemasaran tidak berjalan secara lancar. Hal ini disebabkan konten promosi dan pemasaran produk berenuk pada akun be.renuk ini dijadikan ajang untuk promosi komunitas SUKUN. Sedangkan produk berenuk hanya muncul sebagian kecil saja. Dengan demikina komunitas SUKUN tidak dapat dijadikan andalan untuk mengelola media sosial.

Saat ini instagram yang memiliki akun be.renuk ini dikelola oleh mahasiswa menginjak selama satu bulan, jumlah yang mem'follow' sebanyak 23 orang sedangkan pada link youtube https://youtu.be/wR1r6jI-10k terdapat terdapat 11 orang yang like and subscribe.

\section{Evaluasi karakter mitra sebagai pelaku usaha}

Dari evaluasi selama observasi perilaku pengrajin pak Empud dia memiliki keinginan agar produk kerajinannya dapat dikenal oleh masyarakat Karawang, Jawa Barat, Indonesia bahkan nanti akan mendunia. Berdasarkan hal itu dia terus berkreasi mengembangkan desain kerajinan berenuk. Sejalan dengan visinya tersebut, berdasarkan pesanan yang datang kerajinan tersebut baru dikenal di sebagian masyarakat Karawang, Subang, Sukabumi serta Jepang. Namun mereka belum menjadi pelanggan yang loyal. 
Keberanian menanggung resiko tampaknya belum dimiliki oleh pak Empud, karena dia masih memiliki pekerjaan tetap yaitu sebagai pekerja bangunan. Walaupun pekerjaan inipun tidak tetap sesuai dengan pesanan yang datang.

Selama penelitian berlangsung, pak Empud dapat bekerjasama dengan baik, mampu menerima semua masukan dari tim peneliti dan tampak ingin kreasinya semakin berkembang serta bersedia memperbaiki kekeliruan pada desain maupun produknya sehingga menjadi semakin baik hasilnya.

Salah satu kelemahan pak Empud adalah kurang mengetahui perkembangan model (desain) serta keinginan pasar, hal ini disebabkan kurangnya informasi yang dia terima serta keterbatasan kemampuan dalam mengakses media sosial.

\section{$\underline{\text { Refleksi }}$}

Dari evaluasi di atas dapat dikaji beberapa faktor yang merupakan pendorong kemajuan maupun penghambat usaha kerajinan batok buah berenuk di Dusun Sumedangan.

Faktor pendorong meliputi potensi kerajinan batok buah berenuk menjadi salah satu kerajinan khas Karawang, kemampuan pengrajin dalam membuat produk kerajinan batok buah berenuk serta karakter pendukung, bahan baku yang tersedia di alam dan tidak akan habis, serta bantuan tenaga kerja saat pesanan melimpah.

Potensi kerajinan batok buah berenuk menjadi salah satu kerajinan khas Karawang. Kerajinan berbahan batok buah berenuk masih jarang, sehingga kerajinan ini dapat diangkat menjadi salah satu kerajinan khas Kabupaten Karawang. Suatu produk yang memiliki ciri khas bersumberdaya lokal akan dapat bersaing secara internasional jika disukai oleh calon konsumen. Mengingat hal itu maka perlu pengembangan produk terutama dari segi desain produk.

$\underline{\text { Kemampuan pengrajin dalam membuat produk kerajinan batok buah berenuk serta karakter }}$ pendukung. Pengrajin batok buah berenuk yang bernama pak Empud ini memiliki rasa seni yang tinggi serta menguasai keterampilan dalam membuat kerajinan batok buah berenuk. Modal ini merupakan faktor pendukung yang sangat kuat. Dari beberapa produk yang diminta untuk dibuatkan kerajinan batok buah berenuk memberikan hasil yang memuaskan.

$\underline{B a h a n}$ baku yang tersedia di alam dan tidak akan habis. Tumbuhan berenuk (Crescentia cujete/maja) merupakan tumbuhan liar yang sangat banyak terdapat di Purwadana khususnya 
Dusun Sumedangan yang merupakan daerah banjir, karena merupakan daerah pertemuan dua sungai yaitu Sungai Citarum dan Sungai Cibeet. Tumbuhan ini tumbuh banyak secara liar tanpa dimanfaatkan. Dengan banyaknya tumbuhan ini maka produksi kerajinan berenuk tidak akan kekurangan bahan dasar.

Bantuan tenaga kerja saat pesanan melimpah. Pak Empud tidak bisa berdiri sendiri, perlu dilengkapi oleh tim solid yang memiliki semangat yang tinggi. Kelompok yang menamakan SUKUN (Sumedangan Rukun) merupakan kelompok yang membantu pak Empud terutama jika memerlukan memproduksi kerajinan berenuk dalam jumlah banyak.

Selain faktor pendorong terdapat pula faktor penghambat usaha kerajinan yaitu kurang terpenuhinya karakter pelaku usaha, pandemi COVID-19, kurang pahamnya pengrajin pada penggunaan media sosial.

Menurut Barringer dan Ireland (2012) seorang pelaku usaha yang sukses harus memiliki beberapa karakteristik yaitu memiliki passion terhadap bisnis, fokus terhadap produk dan pelanggan, tidak takut gagal serta memiliki kemampuan untuk mewujudkan suatu ide menjadi bisnis.

Memiliki passion terhadap bisnis. Passion atau ketertarikan terhadap bisnis akan memberikan pengaruh positif terhadap keberlangsungan usaha. Jika hal ini diperhatikan pada sosok pak Empud, maka akan tampak bahwa pak Empud lebih cocok menjadi pengrajin karena dia memiliki passion yang sangat besar terhadap seni dan kerajinan, khususnya pada kerajinan batok buah berenuk yang dia produksi. Tetapi passion untuk menjadi pelaku usaha belum tampak.

Fokus terhadap produk dan pelanggan. Produk yang ditawarkan harus menarik minat maupun kebutuhan pelanggan. Apabila dianalisis Pak Empud memiliki keinginan dan kemampuan yang besar terhadap keinginan pelanggan yang memesan produk tersebut, hal ini tampak dari seluruh yang dipesan pelanggan selalu dipenuhinya dan membuat pelanggan puas. Selain itu dia juga selalu menerima semua masukan perbaikan. Kelemahan dia adalah ketidakmampuannya mengikuti perkembangan pasar tentang kebutuhan kerajinan seperti apa yang dibutuhkan pasar secara umum karena keterbatasan dalam memperoleh informasi terutama informasi melalui teknologi digital.

Tidak takut gagal. Entrepreneur mengambil resiko untuk mencoba sesuatu yang baru, yang penting entrepreneur memiliki keinginan untuk kembali mencoba dan belajar dari kesalahan. 
Pak Empud masih memiliki pekerjaan tetap yaitu sebagai pekerja bangunan, sedangkan membuat kerajinan batok buah berenuk ini hanya sebagai pekerjaan sampingan. Seorang entrepreneur akan berani menanggung resiko jika dia tidak memiliki pekerjaan lain untuk menopang hidupnya. Dari hal tersebut dapat disimpulkan bahwa pak Empud belum memiliki karakter ini.

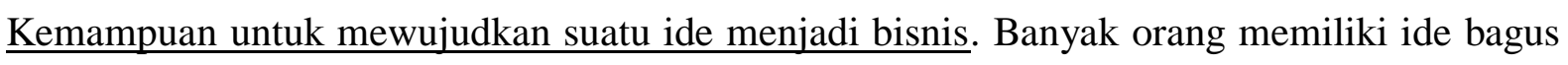
namun tidak bisa mewujudkannya. Seorang entrepreneur yang sukses mampu mewujudkan visi nya menjadi kenyataan. Pak Empud memiliki visi "Dikenalnya produk kerajinan batok buah berenuk khas Sumedangan baik di tingkat regional, nasional maupun internasional". Visi tersebut bukan visi bisnis, karena dengan hanya mengenal saja berarti baru sekedar tahu. Dengan demikian perlu ada mitra yang bisa mengubah masyarakat itu dari hanya sekedar tahu menjadi ingin memiliki produk kerajinan batok buah berenuk Dusun Sumedangan.

Kriya atau kerajinan merupakan salah satu pendukung pariwisata. Kerajinan tangan merupakan potensi untuk mengangkat ekonomi masyarakat maupun pendapatan daerah. Hal ini akan berkembang jika didukung oleh kegiatan wisata. Menurut Retnosary dan Anggela (2019) keberadaan tempat wisata dapat mendorong masyarakat sekitar lokasi tersebut untuk membuka usaha, sehingga dapat meningkatkan pendapatan masyarakat di wilayah tersebut. Saat pandemi COVID-19, hampir seluruh tempat wisata tidak beroperasi bahkan banyak yang bangkrut karena pemerintah membatasi operasi di tempat-tempat keramaian, termasuk tempat wisata dan kegiatan pameran yang biasa diselenggarakan oleh pemerintah daerah atau perusahaan. Hal ini menyebabkan tidak berkembangnya bahkan terhentinya usaha kerajinan khas daerah, salah satunya adalah kerajinan batok buah berenuk ini. Usaha kerajinan yang baru dikenal ini langsung terhenti karena tidak adanya keterhubungan dengan kegiatan promosi dan pemasaran. Pandemi COVID-19 ini juga menyebabkan banyak orang kehilangan pekerjaan, sehinggan berdamopak pada menurunnya prioritas masyarakat dalam pembelian kerajinan. Menurut hasil Manulife Asia Care Survey 2020 terhadap 300 responden di Indonesia, sebanyak $42 \%$ responden jadi lebih sering meninjau dan menata ulang keuangan pribadi semenjak adanya pandemi COVID-19 (https://www.manulife.co.id/id/artikel/pahami-lima-kebutuhanbaru-selama-pandemi-coronavirus.html). Berdasarkan survey ini terdapat 5 (lima) kebutuhan yang menjadi prioritas masyarakat yaitu biaya kesehatan, biaya listrik, online shop, menambah dana kebutuhan darurat dan asuransi. Saat pandemi masyarakat lebih mengutamakan pada kebutuhan pokok yang menunjang kehidupan. 
Dari uraian tersebut dapat disimpulkan bahwa saat pandemi kerajinan tidak dibutuhkan oleh masyarakat, kecuali kerajinan tersebut menjadi alat yang fungsional.

Penggunaan media sosial terutama youtube merupakan sarana yang efektif untuk memperkenalkan dan mempromosikan kerajinan tersebut sehingga dikenal baik secara regional, nasional bahkan internasional. Adanya pandemi yang telah dijelaskan di atas bisa dimanfaatkan oleh pengrajin untuk mengenalkan produknya. Hal inilah yang menjadi dasar penelitian kaji tindak. Namun harapan ini tidak terwujud, karena pengrajin sama sekali tidak dapat memahami penggunaan media sosial. Pelatihan penggunaan media sosial yang telah diselenggarakan lebih banyak dipraktekan oleh komunitas SUKUN dalam membantu mempromosikan kerajinan berenuk melalui instagram be.renuk. Ketidakmampuan pak Empud dalam mengoperasikan media sosial malahan dimanfaatkan oleh komunitas SUKUN untuk lebih mengenalkan komunitas SUKUN, sedangkan kerajinan berenuk hanya sebagian kecil saja dikenalkan. Hal ini disebabkan mereka memiliki kepentingan yang berbeda dengan pak Empud, walaupun saat pembuatan produk mereka tetap akan membantu pak Empud. Penyimpangan ini tentu saja diluar pengawasan pak Empud, karena pengrajin ini tidak dapat melakukan pengecekan.

Faktor lain yang berkaitan erat dengan penguasaan media sosial adalah informasi tentang peluang dan perkembangan pasar. Pak Empud tidak mengetahui informasi tersebut karena dia memiliki keterbatasan dalam penggunaan media sosial.

Dari uraian di atas maka perlunya mitra untuk memulai usaha kerajinan serta membantu dalam menginformasikan peluang dan perkembangan pasar serta pemasaran produk. Mitra tersebut tentu saja bukan pelaku usaha yang sekedar mencari keuntungan tetapi suatu lembaga yang memiliki tujuan untuk membantu masyarakat dalam memajukan usahanya.

\section{KESIMPULAN DAN IMPLIKASI}

\section{Kesimpulan}

Dari hasil penelitian dapat disimpulkan bahwa:

Masyarakat memiliki keinginan, kebutuhan dan selera yang berbeda beda, namun sebagian besar masyarakat cenderumg memiliki minat pada produk kerajinan yang memiliki nilai guna tinggi, desain modern, unik, awet dan memiliki kekhasan daerah Indonesia. 
Produk kerajinan batok buah berenuk memiliki peluang untuk dikembangkan menjadi usaha kerajinan khas daerah Karawang.

Produk kerajinan batok buah berenuk belum memiliki pesaing dalam pasar online, sehingga memiliki peluang untuk dipromosikan dan dipasarkan melalui media sosial.

\section{Implikasi}

Penelitian ini merupakan penelitian awal, sehingga perlu adanya penelitian lanjutan tentang kaji tindak pemasaran batok buah berenuk melalui kemitraan pemasaran, pendampingan promosi dan pemasaran produk serta analisis pelatihan dan pendampingan wirausaha pada produk kerajinan batok buah berenuk.

\section{DAFTAR PUSTAKA}

\section{Buku Teks}

Barringer, B.R. and R.D. Ireland. 2012. Entrepreneurship: Successfully Launching New Ventures. 4th Edition, Boston: Pearson.

Chaffey, D. and Smith, P.R. 2013. E-marketing Excellence: Planning and Optimizing Your Digital Marketing. USA-Routledge.

Creswell, J.W. 2014. Research Design: Pendekatan Kualitatif, Kuantitatif, dan Mixed. Yogyakarta: Pustaka Pelajar.

Kotler, P. and K. L. Keller 2016. Marketing Managemet. Edisi 15 Global Edition. Pearson.

Kotler, P and G. Amstrong. 2018. Principles of Marketing $17^{\text {th }}$ Edition Global Edition. Ebook.

Ryan, D. (2014). Understanding Digital Marketing. Great Britain: Kogan Page Limited.

Sekaran, Uma. 2003. Research Menthod for Bussiness A Skill-Building Approach, 4th ed, New York: John Wiley and Sons,inc.

Sugiyono. 2015. Metode Penelitian Kuantitatif, Kualitatif dan R\&D. Bandung: Penerbit Alfabeta

\section{Jurnal}

Lukitaningsih, A. (2013). Perkembangan Konsep Pemasaran: Implementasi dan Implikasinya. Jurnal Maksipreneur: Manajemen, Koperasi, Dan Entrepreneurship, 3(1), 21

Pandia, R. M., Kadunci, \& Hutagalung, D. D. C. (2017). Pengaruh Kualitas Produk Dan Harga Terhadap Proses Keputusan Pembelian Konsumen Produk Air Mineral Aqua. Epigram, 14(1), 67-76. 
Retnosary, R., F. P. Anggela. 2019. Spinoff effect of tourism attraction to local business performance at Tugu Kebulatan Proklamasi, Rengasdengklok. Journal of Advanted Research in Business and Manajemen Studies 14, Issue 1 25-34.

\section{Sumber internet:}

Thabroni, G. 2019. Teori Seni - Seni Kriya: Pengertian, Sejarah, Fungsi dan Pendapat Ahli. (https://serupa.id/seni-kriya-pengertian-sejarah-fungsi-pendapat-ahli/. Diakses pada $\underline{20 \text { April } 2021}$

Oriflameid. 2021. Lima Syarat Produk Kerajinan yang Perlu Diperhatikan. https://oriflameid.com/syarat-syarat-perancangan-benda-kerajinan/. Diakses pada 20 April 2021.

\section{Dokumen perundangan}

Peraturan Presiden Nomor 72 Tahun 2015 tentang Perubahan Atas Peraturan Presiden Nomor 6 Tahun 2015 Tentang Badan Ekonomi Kreatif

\section{Laporan Penelitian yang tidak dipublikasikan}

Nurlenawati, N., F.P. Anggelina, dan S.P, Fadilla. 2020. Prospek Bisnis Produk Hand Sanitizer (Kasus Fakultas Farmasi UBP Karawang Menghadapi Covid-19). Laporan Hasil Penelitian. Karawang.: LPPM-UBP Karawang.

Putri, I.W. 2017. Pengaruh Pemasaran Digital dan Atribut Produk terhadap Keputusan Pembelian Konsumen pada Distro Papersmooth Bandung. Bandung: Universitas Widiatama. 